\title{
Reprogramming the genome: role of the cell cycle
}

\author{
K. H. S. Campbell and R. Alberio \\ University of Nottingham, School of Biosciences, Sutton Bonington, Loughbrough, \\ Leicestershire LE12 5RD, UK
}

In nuclear transfer reconstructed embryos, the co-ordination of donor nuclear and recipient cytoplasmic cell cycle phases is essential to maintain ploidy and prevent DNA damage. However, the stage of the cell cycle at the time of reconstruction and the method of reconstruction may also have a significant impact on the subsequent development of the embryo and fetus through a number of other mechanisms. This paper reviews some of the information currently available and proposes that consideration of the cell cycle may lead to improvement of methods for embryo reconstruction.

\section{Introduction}

Differentiated somatic nuclei acquire totipotency after transplantation into oocytes, as shown by the generation of live offspring in a number of species, including sheep (Wilmut et al., 1997a), cattle (Cibelli et al., 1998b), mice (Wakayama et al., 1998a), goats (Baguisi et al., 1999), rabbits (Chesne et al., 2002) and a cat (Shin et al., 2002) and a mule (Woods et al., 2003) (for a review, see Campbell et al., 2001). This reversal of the differentiated state of a somatic nucleus by nuclear transplantation is referred to as nuclear 'reprogramming'. Early studies conducted in amphibians show the capacity of differentiated nuclei to re-direct their gene expression pattern dependent upon nuclear remodelling factors present in the cytoplasm of the oocyte (Di Berardino and Hoffner, 1983). It has been suggested that remodelling of the donor chromatin is essential for proper gene expression in reconstructed embryos. The capacity of the oocyte for nuclear reorganization is demonstrated by the replacement of sperm protamines by oocytic histones after fertilization in mammals (Perreault, 1992). In cloned embryos, the nuclear modifications have been partially studied and some conclusions from these studies indicate that certain conditions have to be taken into account to ensure that development occurs, Initial studies in mammalian nuclear transfer embryos show the importance of cell cycle co-ordination between the donor nucleus and the recipient cytoplast to ensure development (Collas et al., 1992; Campbell et al., 1993, 1994).

It is now accepted that two main types of recipient oocyte are suitable for development to term after single nuclear transfer (NT) (Fig. 1). The difference between these two recipient oocytes is essentially the amount of maturation promoting factor (MPF), a cytoplasmic protein kinase involved in both mitotic and meiotic division (for a review, see Campbell et al., 1996b). All nuclei transferred at the time of activation when MPF contents are high (Fig. 1a) undergo nuclear envelope breakdown, which is followed by premature chromosome condensation (PCC). The nuclear envelope is then reformed and DNA synthesis is observed in all nuclei. In 
(a) Cytoplast with high MPF activity: Simultaneous activation and fusion

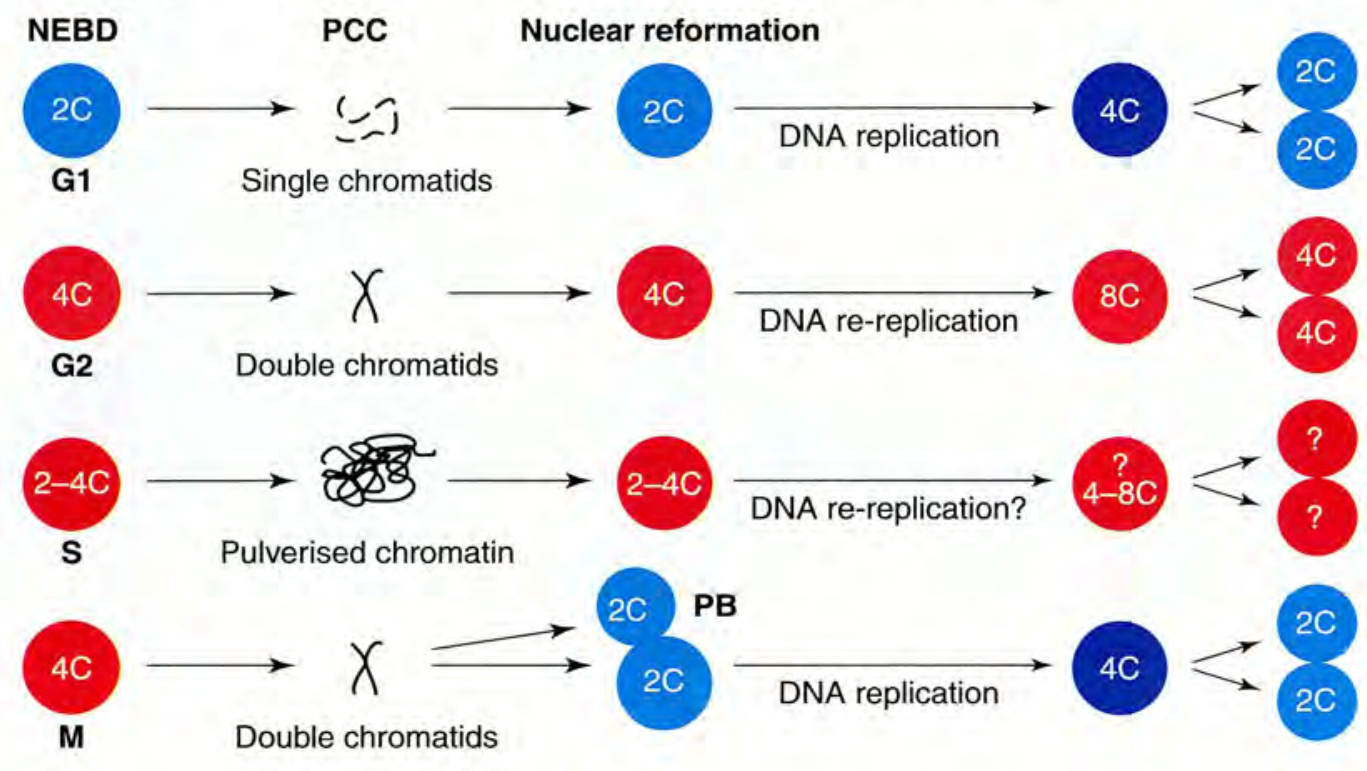

(b) Cytoplast with low MPF activity: Fusion after activation

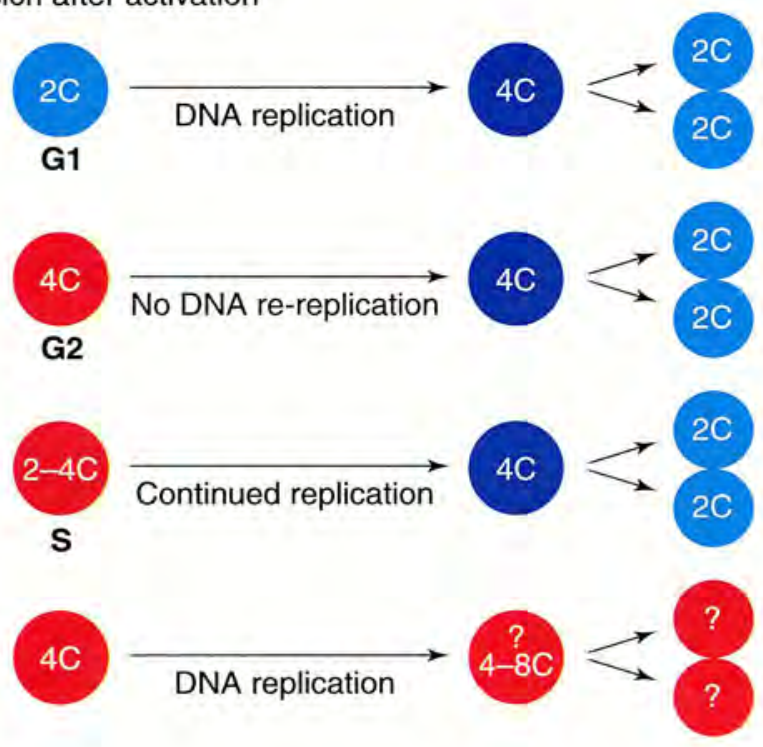

Fig. 1 (a)-(d). For legend see facing page.

this situation it is probable that unless the nucleus is diploid (G1-G0) at the time of transfer, re-replication of previously replicated DNA will occur and that, at the end of the first cell cycle, the DNA content (ploidy) of the nuclei in the daughter cells will be incorrect. The increased amount of DNA present at the end of the first cycle may also adversely affect mitosis resulting in unequal segregation or possible chromosomal abnormalities. Although live offspring have been reported from each of these cell cycle combinations in a range of 
(c) Cytoplast with high MPF activity: Activation after fusion

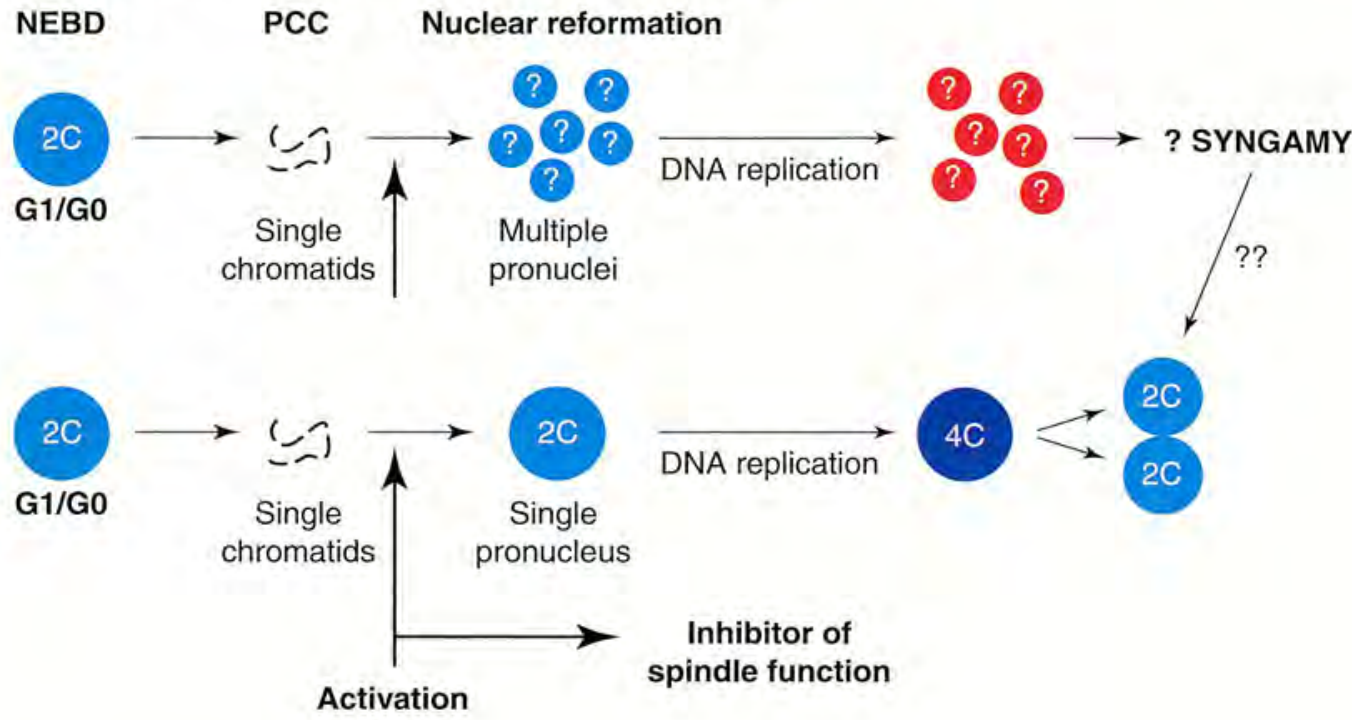

(d) Cytoplast with high MPF activity: Activation after fusion

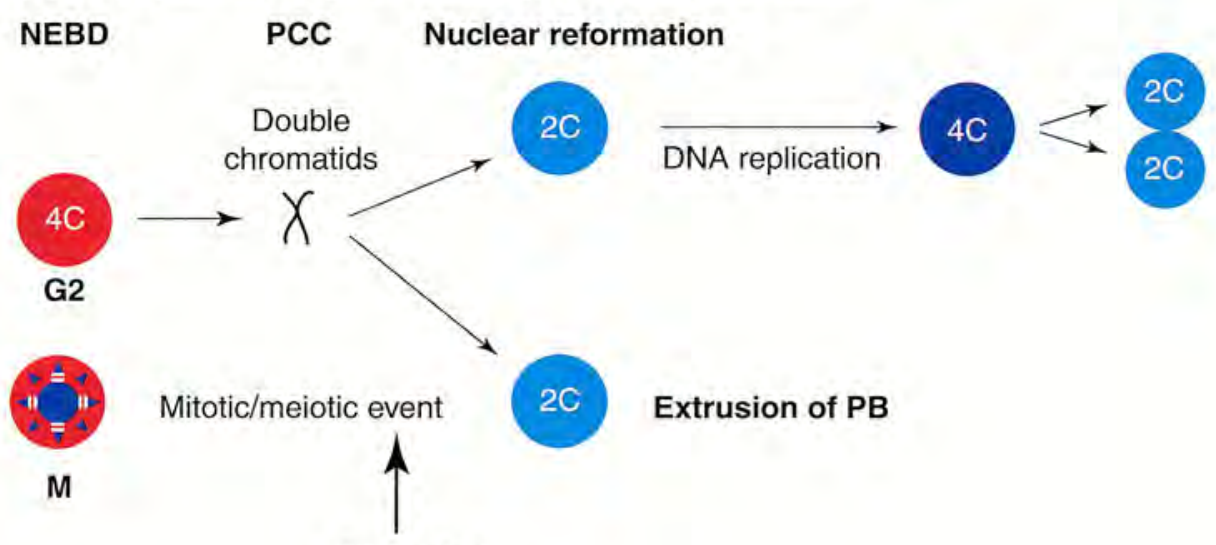

\section{Activation}

Fig. 1. Effects of nuclear transfer of karyoplasts at defined stages of the cell cycle into cytoplasts at defined stages of the cell cycle on chromatin fate, DNA replication and ploidy of resultant daughter cells. (a-d) In this diagrammatic representation, red circles represent nuclei that are 'out of phase' in terms of DNA content with the stage of the cell cycle of the recipient cytoplast, whereas the blue circles represent nuclei that are 'in phase'. M: mitosis; MPF: maturing promoting factor; NEBD: nuclear envelope breakdown; PB: polar body; PCC: premature condensation.

species (Table 1), the occurrence of the events depicted diagramatically may vary depending upon the species and the age of the recipient cytoplast. In contrast, when nuclei are transferred after the disappearance of MPF activity (Fig. 1b), no nuclear envelope breakdown or PCC are observed. Nuclei that are in G1 or S phase at the time of transfer initiate or continue DNA synthesis, respectively; however, no DNA synthesis is observed in nuclei that are in the 


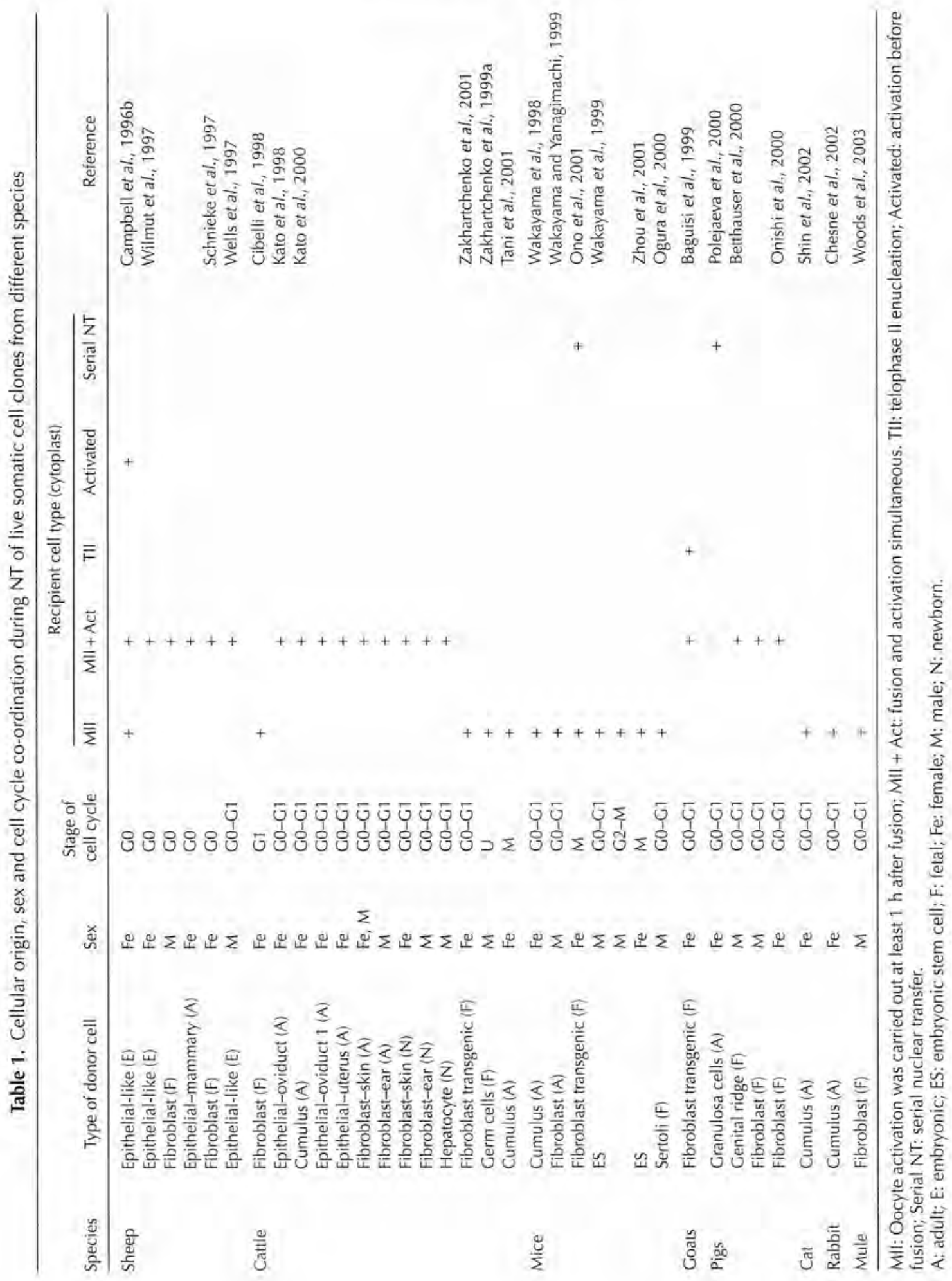


G2 phase. As cells at different stages of the cell cycle can develop after transfer into preactivated oocytes, this type of oocyte has been termed 'a universal recipient' (Campbell et al., 1993).

The transfer of M-phase chromatin into pre-activated oocytes has also been reported; however, the fate of the transferred chromatin has not been described (Tani et al., 2001b). It is hypothesized that $\mathrm{M}$-phase chromatin would decondense and form a tetraploid (4C) nucleus that would undergo DNA synthesis; however, this would be dependent upon the cell cycle phase of the recipient (Fig. 1b). If the recipient was at the late stage of the cycle, it is possible that MPF activity may be increasing and M-phase chromatin would enter the first mitotic division and result in daughter cells with diploid pronuclei (Fig. 2).

It has been suggested in both mammals (Czolowska et al., 1984; Szollosi et al., 1988) and amphibians (Hoffner and Di Berardino, 1980; Leonard èt al., 1982; Di Berardino and Hoffner, 1983) that optimal reprogramming of the donor nucleus is obtained when the recipient cytoplast remains at MII (unactivated, high MPF activity). In this situation, the fate of the donor chromatin is dependent not only upon the stage of the cell cycle of the donor nucleus but also on the species and the period between fusion and subsequent activation. On short exposure the effects would be as described in Fig. 1a. However, on prolonged exposure a number of effects have been reported. PCC and spindle formation occur, but spindle organization is often disrupted (Czolowska et al, 1984). In some cases, multiple pronuclei are observed (Fig. 1c) (Campbell and Wilmut, 1999); however, this can be avoided by the use of inhibitors or stabilizers of spindle formation, such as Nocodazole (Campbell and Wilmut, 1996) or other agents, such as di-methyl amino purine (Campbell and Eyestone, 1998). In the absence of such treatments it is unknown whether the multiple pronuclei undergo syngamy at the first mitosis and result in diploid daughter nuclei. When a spindle is formed, a diploid pronucleus and a polar body are formed subsequently (Fig. 1d), for example in mice (Kwon and Kono, 1996) and cattle (Alberio et al., 2000).

Although cytoplast recipients can be divided into two main types based on MPF activity, further cytoplast recipients can be defined on the basis of the cell cycle stage at the time of enucleation, the MPF activity and the period of exposure of the donor chromatin to cytoplasmic factors. Four main types of cytoplast recipient can be produced from MII oocytes (Fig. 2).

The cell cycle of the donor cell may also affect development (Campbell et al., 2001) (Table 1). Development to term has been reported in many studies using G0 donor cells from sheep (Campbell et al,, 1996b; Wilmut et al., 1997b), cattle (Kato et al., 1998b; Wells et al., 1999), mice (Wakayama et al., 1998a) and cats (Shin et al., 2002). Although it has been suggested that donors in the G0 phase may be more amenable to nuclear reprogramming (Campbell et al., 1996c), live offspring have also been obtained using nuclear donors in the G1 phase, as in cattle (Cibelli et al., 1998b). In addition, M-phase cells have also been used successfully for NT into MII arrested oocytes in mice (Wakayama et al., 1999a), sheep (Liu et al., 1997) and cattle (Alberio et al., 2000; Tani et al., 2001b). Although recent studies in cattle support the previous hypothesis that G0 donors may be beneficial to development when using primary cell populations (Wells et al., 2003), the overall efficiency remains at $1-3 \%$ in any species (Gurdon and Colman, 1999).

The reasons for the low efficiency of this technique are little known; however, functional studies have shown aberrant genomic methylation, unstable patterns of imprinting and gene expression in embryos reconstructed by NT. Furthermore, studies investigating structural remodelling show the formation of multinuclei in zygotes and abnormal nucleolar structure during early development in cloned embryos (Hyttel et al., 2001; Baran et al., 2002; Laurincik et al., 2002). In this review, we aim to discuss the significance of the cell cycle of donor and 
(a) Fusion prior to activation (prolonged high MPF)

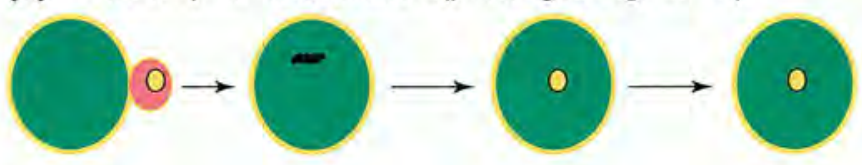

(b) Fusion and activation (high MPF declining)

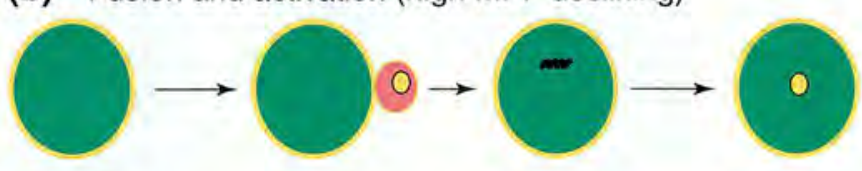

(c) Activation before fusion (low MPF)

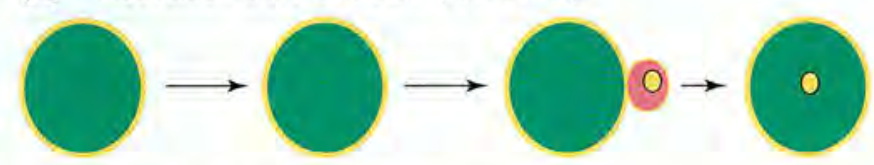

(d) Activation before fusion (rising MPF)
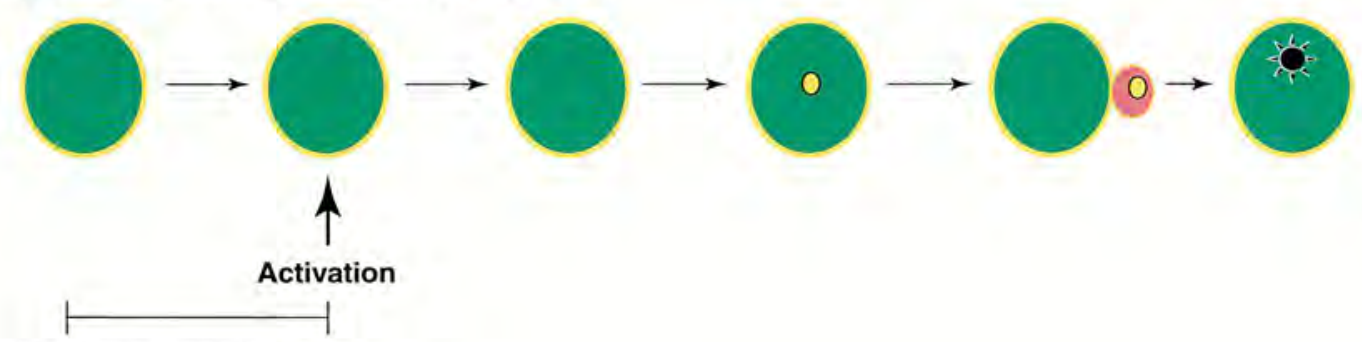

Variable period of exposure

to MII cytoplasm in method $A$

Fig. 2. Diagrammatic representation of major cytoplast recipients prepared from MII oocytes. The cytoplast recipients differ in their maturation promoting factor (MPF) activity and the period of exposure of the donor chromatin to MPF activity. (a) These cytoplasts have high MPF activity. Transfer of the donor cell is carried out before activation, nuclear envelope breakdown and premature condensation would occur. The period of exposure of the condensed chromatin to the recipient cytoplasm can be varied by delaying activation. (b) In these recipients, the oocyte is activated simultaneously with transfer of the donor nucleus; the period of exposure is dependent upon the time required for transfer (that is, injection versus fusion) and the rate of decay of MPF activity (dependent upon species and age of oocyte). (c) In these cytoplasts, MPF activity is minimal at the time of transfer of the donor nucleus. (d) In these cytoplasts, it is possible that donor nuclei could be transferred as MPF activity increases. Thus, G2 or M-phase chromatin would immediately enter a mitotic division; however, there are no reports of this in the literature. Other variations to these cytoplast recipients can be produced dependent upon the timing of enucleation, telophase 1 or telophase II for instance or enucleation after transfer.

recipient cytoplast on chromatin remodelling and gene expression in cloned embryos and to integrate cell cycle controls with embryonic and fetal development.

\section{Effects of cell cycle on chromatin remodelling}

It has been suggested that nuclear envelope breakdown and PCC are two essential structural remodelling events required for correct gene expression in NT embryos (Collas et al., 1992). 
Nuclear envelope breakdown induced by high MPF activity of an MIl recipient oocyte facilitates the access to the chromatin of factors present in the cytoplasm. The effects of the cell cycle stage of the donor and recipient at the time of reconstruction have been studied using a number of reported markers of chromatin remodelling.

\section{Histone $\mathrm{H1}$}

Histone $\mathrm{H} 1$ immunoreactivity after nuclear transplantation has been demonstrated in mouse and cattle embryos (Bordignon et al., 2001). The loss of somatic $\mathrm{H} 1$ immunoreactivity is more efficient and rapid when either the donor nucleus or the recipient cytoplast is at $\mathrm{M}$ phase. Moreover, when the recipient oocyte is not enucleated, no loss of $\mathrm{H} 1$ immunoreactivity occurs in the transferred nucleus, indicating that cytoplasmic factors accumulate in the host nucleus and are not available to remove somatic $\mathrm{H} 1$ from the transferred nucleus. This observation may explain the significance of the removal of the nuclear component during the enucleation process and its influence on nuclear reprogramming and, in particular, may explain the failure of enucleated zygotes as cytoplast recipients.

\section{Histone $\mathrm{H} 4$ acetylation}

Histone $\mathrm{H} 4$ acetylation is another modification that occurs in normally fertilized embryos. In the mouse, the sperm chromatin decondenses shortly after fertilization and becomes acetylated. This is followed by the acetylation of the maternal chromatin, so that by the time syngamy occurs both genomes show a similar pattern of acetylation (Adenot et al., 1997). In contrast, although the chromatin of the MII arrested oocyte shows very low amounts of acetylation, after parthenogenetic activation the maternal chromatin becomes highly stained. This finding indicates that the process of genome acetylation is dependent upon oocyte activation, either by the spermatozoa or an artificial stimulus, and that the sperm chromatin out-competes maternal chromatin for hyper-acetylated H4 (Adenot et al., 1997). This finding is supported by McLay et al. (2002a) who reported that the ability to transfer histones into spermatozoa is acquired during oocyte maturation and is $\mathrm{Ca}^{2+}$-dependent. Histone $\mathrm{H} 4$ acetylation activity is linked to transcriptionally active genetic loci (Vettese-Dadey et al., 1996) and is independent of the DNA synthetic activity of the oocyte (Adenot et al., 1997). It now remains to be shown whether NT embryos reconstructed by fusing a donor cell into a pre-activated oocyte will undergo the same level of acetylation as embryos reconstructed with MII oocytes. These studies will provide information about the importance of histone acetylation and transcriptional activity in cloned embryos.

\section{DNA methylation}

DNA methylation is another epigenetic modification that the genome undergoes during early embryogenesis (Monk et al., 1987); however, its exact regulation during early development has not been fully elucidated. In Xenopus laevis, promoter regions of genes involved in early embryonic development are preferentially demethylated at the mid-blastula transition when genomic transcription occurs (Stancheva et al., 2002). This passive demethylation may be the result of competition between transcription factors present in the form of maternal RNAs and proteins, and decreasing amounts of the maintenance methyltransferase enzyme (Dnmt1) in the early embryo (Matsuo et al., 1998). This hypothesis is supported by the fact that early gene activation in $x$ Dnmt1-depleted embryos is restricted to genes activated at the mid-blastula transition, whereas unmethylated promoter regions of genes that are normally not transcribed at this stage are not activated (Stancheva et al., 2002). In mice, it has been 
shown that demethylation of the male genome is accomplished as early as $4 \mathrm{~h}$ after fertilization by an active process (Mayer et al., 2000; Oswald et al., 2000). This is followed by further passive demethylation up to the morula stage. By the time of blastocyst formation de novo methylation takes place in the inner cell mass, but not in the trophectoderm cells (Santos et al., 2002). The pattern of genomic demethylation in the bovine embryo after IVF is similar to that of the mouse embryo up to the eight-cell stage; however, de novo methylation has been reported in later developmental stages, including trophectoderm cells of the blastocyst (Dean et al., 2001). In bovine embryos produced by NT, several studies have shown aberrant methylation patterns during preimplantation development (for reviews, see Han et al., 2003; Reik et al., 2003). Bovine cloned embryos reconstructed with fetal cells showed a reduction in methylation at the one-cell stage, but re-methylation occurred at early stages, resembling the methylation pattern of the donor cell when the embryo reached the morula stage (Dean et al., 2001). In another study carried out with embryos reconstructed using adult skin fibroblasts as nuclear donors (Bourc'his et al., 2001), there was an absence of demethylation during the first three cell divisions and some euchromatin demethylation occurred from the eight-cell stage. From the morula stage, the euchromatin was undermethylated; however, in contrast to embryos produced in vitro, centromeric heterochromatin remained methylated in clones. A recent study using bisulphite treatment reported a differential methylation of euchromatic and heterochromatic sequences in NT embryos and also an abnormal hypermethylation of trophectoderm cells in bovine clones (Kang et al., 2002). Demethylation of heterochromatic and euchromatic repeats has also been shown in pig embryos derived both in vivo and in vitro (Kang et al., 2001b). Moreover, this demethylation pattern was shown to be similar in pig somatic clones (Kang et al., 2001b). This finding contradicts the results obtained in bovine embryos indicating that there may be species differences in the mechanisms of epigenetic reprogramming. Another interesting study reported in bovine tetraploid clones shows an increased demethylation of embryos reconstructed in the presence of the maternal chromosomes, that is without removal of cytoplasmic components present in the vicinity of the metaphase plate of the matured oocyte (Kang et al., 2001c). This finding indicates compartmentalization of factors involved in chromatin remodelling in the oocyte, the distribution of which may also be influenced by the status of the chromatin in the oocyte. Together these studies have shown similarities and differences, this may in part be due to the technical procedure; however, there may also be differences as a result of the biological material. For instance, it has been shown that fetal cells have greater methylation of euchromatin when compared with the pattern in aged fetal cells (Kang et al., 2001a); however, whether these differences are also observed in vivo remains to be elucidated. It should also be considered that these groups adopted different methods of embryo reconstruction. Young, matured oocytes were used as recipient cytoplasts in the studies of both Dean et al. (2001) and Kang et al. (2002); the results indicate that the donor chromatin was exposed to high amounts of MPF for at least $2 \mathrm{~h}$ before oocyte activation was conducted. The exposure to high amounts of MPF may be a determinant for epigenetic reprogramming of the genome in cloned embryos. In the study of Bourc'his et al. (2001), aged oocytes with lower amounts of MPF were used. Presumably, the chromatin of the transferred nucleus started DNA replication earlier than those transferred into MII arrested oocytes, without undergoing the same epigenetic reprogramming. This hypothesis is supported by the fact that development to blastocysts is significantly improved when young MII oocytes are used in comparison with aged oocytes (Vignon et al., 1998; Zakhartchenko et al., 1999b; Zakhartchenko et al., 2001); however, full-term development related to transferred embryos does not differ between the two approaches. Bovine embryos reconstructed in an environment of low MPF may undergo only minor epigenetic reprogramming and as a consequence they are unlikely to develop beyond the blastocyst stage. No 
final conclusions can yet be made about genomic methylation after NT; however, analysing specific sequences of the genome (Stancheva et al., 2002) and considering the methods used for embryo reconstruction may help in the understanding of epigenetic reprogramming.

\section{$X$ chromosome inactivation}

An example of epigenetic modification after NT is the inactivation of the X chromosome in reconstructed embryos. In cloned mice, $X$ chromosome inactivation occurs in both trophectodermal and embryonic tissues (Eggan et al., 2000b). In cattle, the paternal X chromosome is inactive in placental tissue of normal clones and bovine fetuses from natural reproduction, whereas both X chromosomes are active in placentae from deceased clones (Xue et al., 2002). Abnormal X chromosome inactivation in the trophectoderm leads to fetal loss in cloned cattle. Fetal abnormalities and low viability have been reported with different NT protocols, indicating that the methods for embryo reconstruction used at present do not facilitate correct reprogramming of the somatic nucleus.

\section{Gene expression in early embryos}

Early development is characterized by a switch from maternal transcripts to zygotic transcripts that direct development. Activation of the embryonic genome is species-dependent and related to epigenetic modifications of the chromatin (for a review, see Kanka, 2003). In bovine NT embryos, RNA synthesis is dependent upon the stage of the cell cycle of the recipient oocyte; activated cytoplast recipients (with low MPF activity) are less able to inhibit transcription from the transferred nucleus than MII cytoplasts (high MPF activity). In addition, RNA synthesis is detectable at the four-cell stage in embryos reconstructed with activated cytoplasts but not in embryos reconstructed with MII cytoplasts (Kanka et al., 1999). The effect of the exposure of the donor cell to high MPF activity has also been analysed upon expression of developmentally important genes in somatic clones. A delay of $4 \mathrm{~h}$ between fusion and activation leads to an increased number of embryos expressing FGF4 in cattle clones (Daniels et al., 2001). Moreover, the expression of interferon $\tau$ is higher in embryos reconstructed by simultaneous fusion and activation compared with embryos in which the fusion activation interval was 3-5 h. Recent studies indicate that early and high expression of interferon $\tau$ are indicative of poor quality embryos (Kubisch et al., 1998). In contrast the mRNA contents of the HSP70.1, MASH2 and DNMT are not affected by the time of exposure to MPF, but depend on the stage of the cell cycle of the donor cell (Wrenzycki et al., 2001).

\section{Possible role of cell cycle control in growth and development of NT embryos}

During its lifetime, a single cell must duplicate all of its components and give rise to two daughter cells that are identical to each other and identical to the parent cell at birth. The events that occur during a single growth cycle can be divided into the 'nuclear division cycle' and the 'growth cycle'. In an actively proliferating population of cultured cells, the cells maintain a constant macromolecular composition, and a constant size and shape. This requires the co-ordination of the nuclear and growth cycles. Cell growth and division are dependent upon external proliferative signals; however, the mechanisms by which growth and division are co-ordinated are unknown, although a range of mechanisms have been 
suggested (for reviews, see Neufeld and Edgar, 1998; Polymenis and Schmidt, 1999; Tapon et al., 2001). The mechanisms that have been suggested include the following:

(1) Cell division drives cell growth. This proposal is that growth is a consequence of the nuclear division cycle. However, a number of observations indicate that this is unlikely, Firstly, if the amount of the G1 cyclins is increased, there is no increase in growth rate and a decrease in cell size is observed: that is, Cln3 in yeast Nash et al., 1988), cyclin D1 or E in mammalian cells (Ohtsubo and Roberts, 1993; Quelle et al., 1993; Resnitzky et al., 1994) or in C. elegans by inhibiting the proteolysis of cyclins (Kipreos et al., 1996). Secondly, if the cell division cycle is blocked, growth continues resulting in larger cells (Johnston et al., 1977; Neufeld and Edgar, 1998).

(2) Growth drives cell division. During the G1 phase of the cell cycle there is a restriction point termed 'Start' or ' $R$ ': to pass this point cells must attain a critical size or a certain biosynthetic capacity. However, experiments have shown that activation of G1 cyclin-cdk complexes is sufficient for the G1-S-phase transition. An example of this is given by the yeast CLN3 gene (yeast G1 cyclin). The product of this gene initiates a START transcriptional programme including transcription of other G1 cyclins (Wittenberg and Reed, 1996). Cln3p is unstable; however, amounts remain more or less constant during the cell cycle possibly regulated by its synthesis. The amount of Cln3p is sensitive to the number of active ribosomes in a cell. As growth decreases there are fewer ribosomes and less $C \ln 3 p$. As growth increases more ribosomes accumulate and increased amounts of $C \ln 3 p$ are found. When cells are starved, there is a decrease in the number of ribosomes and a decrease in Cln3p, indicating translational control (Gallego et al., 1997; Polymenis and Schmidt, 1997). This type of translational control has also been reported for a number of other cell cycle-related genes, including CDK4 and its partner cyclin D1, p27 (Kip1) and MDM2 (reviewed by Neufeld and Edgar, 1998). Therefore, expression may be restricted to conditions favouring maximal growth. Studies carried out in yeast indicate that commitment to cell division is linked to signals that direct ribosome biosynthesis. Thus, the cell is able to adjust the critical cell size threshold before a change in ribosome content and protein synthetic rate occurs (Jorgensen et al., 2002). The interplay between ribosome assembly and cell cycle progression appears to be conserved in higher eukaryotic cell division (Kozma and Thomas, 2002).

(3) Control of growth and division is co-ordinated. Both growth and division cycles respond to a common signalling pathway. There are several examples of this type of co-ordination (for reviews, see Neufeld and Edgar, 1998; Polymenis and Schmidt, 1999; Tapon et al., 2001) including:

- TATA box binding protein associated factors (TAFs). In yeast, yTAFs target G1-S-phase cyclins and growth genes (that is, ribosomal proteins) and are responsive to growth state. An increase in growth rate is accompanied by an increase in yTAF, and inactivation of TAF causes G1 arrest.

- RAS. RAS activates MAP and PI3-kinase pathways both of which target translation initiation factors and p70 S6 kinase which modulate protein synthesis. This stimulates S-phase progression via stimulation of CDK activating phosphatases, inactivation of $\mathrm{p} 27^{(\mathrm{kip})}$ and upregulation of cyclin E expression.

- Myc. Myc may promote growth via transcriptional activation of genes involved in protein synthesis including ribosomal components and translation initiation factors $R b$. This tumour suppressor gene has effects on a number of processes including inhibition of transcription via inhibition of RNA polymerases I, II and III. 
Table 2. Genotypes and phenotypes of murine cell cycle gene knockouts

\begin{tabular}{|c|c|c|}
\hline Genotype & Phenotype & Reference \\
\hline $\mathrm{RB}-1-$ & $\begin{array}{l}\text { Embryonic lethal, neurogenesis } \\
\text { and haematopoiesis }\end{array}$ & Lin et al., 1996 \\
\hline $\mathrm{RB}+\mathrm{L}-$ & Viable, thyroid and pituitary tumours & Lin et al, 1996 \\
\hline $\mathrm{P} 27-1-$ & $\begin{array}{l}\text { Gigantism, pituitary hyperplasia, infertility } \\
\text { in females }\end{array}$ & $\begin{array}{l}\text { Kiyokawa et al., 1996; } \\
\text { Nakayama et al., 1996; } \\
\text { Fero et al., 1996; } \\
\text { Nagahama et al., } 2001\end{array}$ \\
\hline $\mathrm{P} 18-1-\mathrm{P} 18-\downarrow-\mathrm{p} 27-\downarrow$ & Gigantism & Franklin et al., 1998 \\
\hline P57 - $1-$ & $\begin{array}{l}\text { Defects in kidneys, long bones, } \\
\text { eye lens, abdominal wall }\end{array}$ & Zhang et al., 1997; Yan et al., 1997 \\
\hline $\mathrm{P} 27-1-\mathrm{p} 57-1-$ & $\begin{array}{l}\text { Increased embryonic lethality, } \\
\text { placental defects }\end{array}$ & Zhang et al., 1998 \\
\hline
\end{tabular}

- P53. P53 is involved in DNA damage mediated cell cycle arrest. It inhibits RNA pol III, possibly via TFIIIB and may be linked to nucleotide pools.

- Insulin. The insulin mediated signalling pathway causes phosphorylation of ribosomal protein $\$ 6$ which may increase the translational capacity of the cell via production of ribosomal components and translation initiation factors.

(4) There is independent regulation of growth and division. There are many exceptions to the co-ordination of growth and division cycles during development. For example in Drosophila, embryonic cycles before hatching are growth independent and rely on oocyte stores (Edgar and Lehner, 1996), Similarly, in Xenopus during early cycles, the G1 phase of the cell cycle is absent and no growth occurs (Kirschner et al., 1985).

In addition to co-ordinating cell growth with division cycles, these cycles must also be coordinated with differentiation, cell death and tissue-specific compartmental controls. It is probable that a range of control mechanisms is involved in co-ordinating these events. In mammalian embryos during early cycles there is little transcription from the zygotic genome and cell division is associated with a reduction in cell size, again indicating an uncoupling of these two events and possibly the involvement of maternally inherited factors in early division cycles. Numerous mechanisms and feedback controls have been described in co-ordinating the nuclear division cycle, that is completion of S-phase before initiation of M-phase (Cerutti and Simanis, 2000; Lew, 2000). The controls operating during mammalian embryogenesis are poorly described; however, species differences are evident. As described above, the cell cycle phase of the recipient and donor cells can have profound effects on the remodelling of donor chromatin. The frequency of successful development to term and survival of embryos reconstructed by NT is extremely low. It has been suggested that only a small percentage of donor cells can be reprogrammed and that those embryos that develop may represent a sub-population of donor cells. An alternative explanation is that only a small percentage of recipient cells are able to 'remodel' and 'reprogramme' the donor nucleus; however, in practice a range of factors is probably involved. The co-ordination of cell growth and division is essential for normal development. The effects of the culture environment upon this coordination have been essential in defining some of the controls described above. The culture environment has also been implicated in epigenetic modification of murine ES cells and in the 
(a) Schematic representation of double nuclear transfer

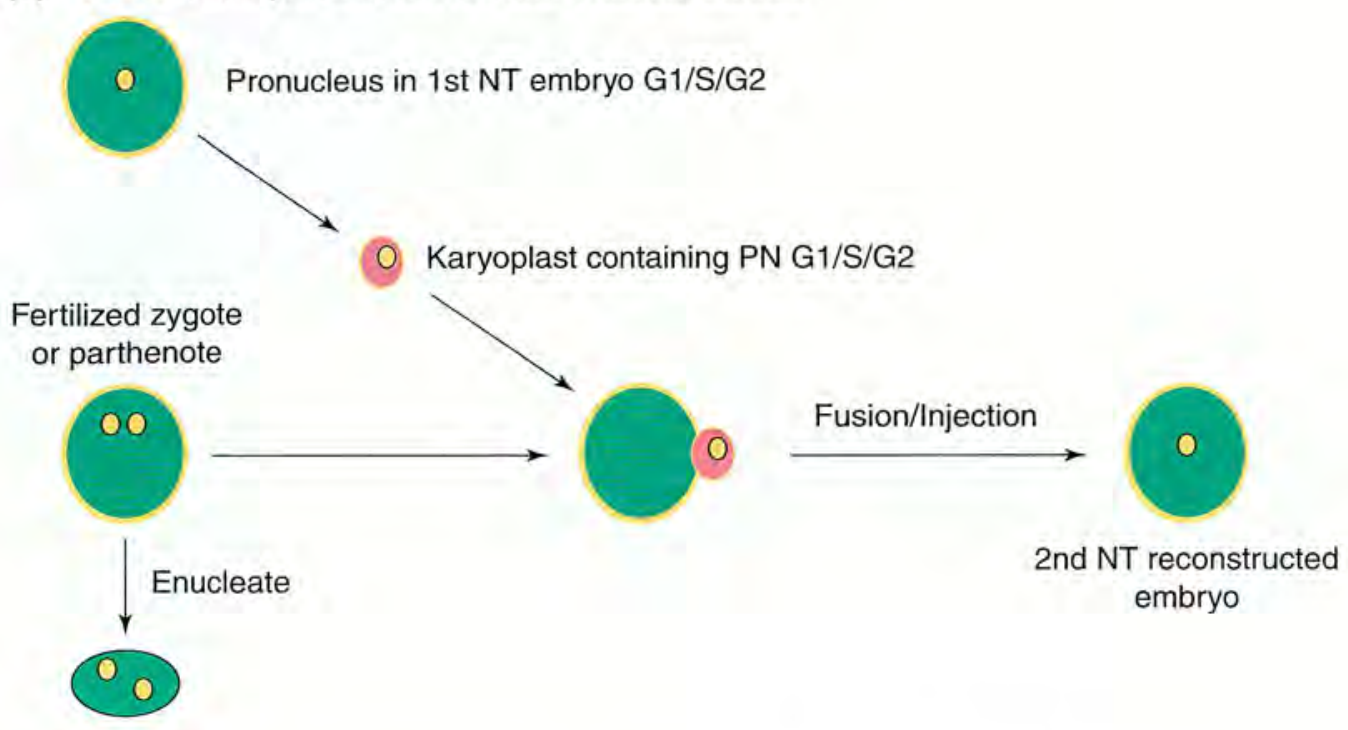

(b) Production of two diploid pronuclei by transfer of G2-M phase nuclei to cytoplast with high MPF activity and inhibition of polar body extrusion

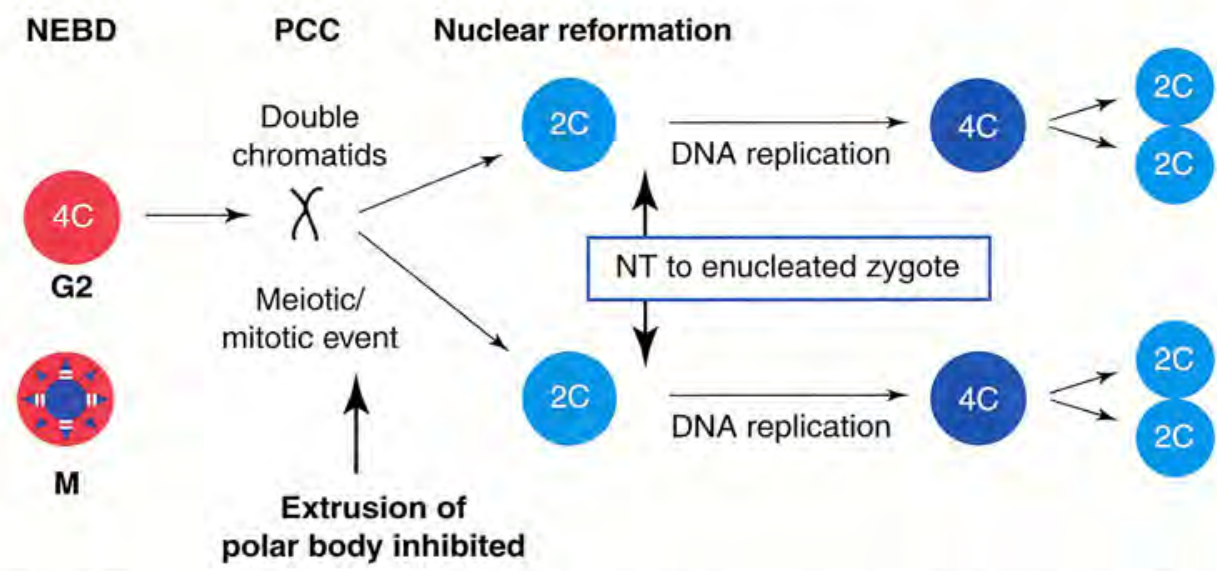

Fig. 3. (a) Diagrammatic representation of the double nuclear transfer (NT) procedure. A diploid pronucleus produced by any of the methods outlined in Figs 1 and 2 may be transferred to an enucleated zygote or parthenote. Both the donor karyoplast and the recipient cytoplast have low maturing promoting factor (MPF) activity by definition, as defined by the presence of an intact pronucleus. In this situation, DNA replication would appear to be co-ordinated between donor and recipient cells. (b) In addition to the methods outlined in Figs 1 and 2, a suitable donor pronucleus may be produced from a tetraploid zygote when polar body extrusion is inhibited (Kwon and Kono, 1996). NEBD: nuclear envelope breakdown; PCC: premature condensation; PN: pronucleus.

development of NT reconstructed embryos, further linking cell cycle control, development and differentiation. In addition, experiments in which cell cycle regulatory genes have been knocked out in mice have resulted in a range of developmental phenotypes (Table 2). Many of these phenotypes resemble the abnormalities observed during development of NT derived 
embryos or fetuses, including increased embryonic or fetal lethality, organomeglia, skeletal defects, lung defects and placental defects.

As described above, the presence or absence of the MII spindle in oocytes used as cytoplast recipients has been shown to effect chromatin remodelling. In addition, we hypothesise that removal of the MII spindle (enucleation) may also cause perturbations in cell cycle control, which could have long lasting consequences and contribute to developmental failure of NT derived embryos. Many of the proteins that are involved with cell cycle control are associated with the mitotic or meiotic spindle, including MPF (Czolowska et al., 1986), c-mos (Zhou et al., 1991; Wang et al., 1994) and Cdks (Jiang et al., 1998; John et al., 2001; Menssen et al., 2001; Mollinari et al., 2002; Yoshida et al., 2002). The effects of depleting the oocyte of these proteins on subsequent development are unknown; however, several reports provide indirect evidence of their possible role. Studies on the use of bovine and murine oocytes enucleated at telophase II following activation indicate a greater frequency of development (Bordignon and Smith, 1998; Baguisi and Overstrom, 2000). In humans, a single report on the production of embryonic stem cells from NT reconstructed embryos indicated that NT must be carried out before enucleation for the technique to be successful (Meek, 2001). In both of these situations, it is possible that cell cycle-related proteins have been released from the oocyte chromatin before enucleation and, therefore, may remain in the cytoplast in higher concentrations. Other indications stem from the results of studies using a double nuclear transfer procedure (Fig. 3). In this technique, the first nuclear transfer uses an enucleated metaphase II oocyte as cytoplast recipient. The resultant diploid pronucleus is then transferred into an enucleated, fertilized zygote. This technique has been used successfully in pig cloning (Polejaeva et al., 2000), and studies in mice have indicated that this technique results in fewer abnormalities (Ono et al., 2001). These observations may result from a number of factors, including increased activation due to the use of spermatozoa, or the presence of paternal transcripts or proteins; however, it may also be that by using this procedure the final reconstituted embryo contains a more physiological content of oocyte proteins which contribute to development of the embryo. Other modifications to the techniques used for embryo production also appear to increase the frequency of development and reduce developmental abnormalities, for example the in vivo culture of both pig and goat NT embryos (Baguisi et al., 1999; Polejaeva et al., 2000) or the use of embryonic stem cell tetraploids in mice (Eggan et al., 2000a). One explanation of these observations is that the effects of NT and the culture environment on development are interactive and may occur through mechanisms involving cell cycle controls particularly during the early cleavage cycles.

\section{Conclusion and perspectives}

Nuclear transfer has numerous roles to play in both research and application; these include animal production and biotechnology, gaining a greater understanding of the mechanisms controlling early development, improving reproductive techniques, the production of autologous stem cells for human therapeutics and genetic conservation (for a review, see Campbell, 2002). At the present time, the efficiencies of the current techniques limit application in several of these areas; however, NT has provided a route for complicated genetic manipulation including double gene knockouts in pigs for research on xenotransplantation (Phelps et al., 2003) or the use of artificial chromosome vectors for the expression of complex proteins, such as human antibodies, in transgenic cattle (Robl, 2003). In the areas of genetic modification the low efficiencies are balanced against the need for the production of only founder animals which cannot be produced by other means at present. For animal production again the benefit of genetic conservation may exceed the low efficiencies; however, as a means for routine 
animal production the low efficiencies coupled with the developmental abnormalities reported outweigh the benefits. Improving the frequency of development of embryos produced by NT is a major goal of present research. Studies on the cell cycle proved essential to increasing the frequency of development of embryos created by NT using embryonic blastomeres as nuclear donors and in creating the first mammals by NT from cultured differentiated cell populations. Early studies demonstrated the requirement for cell cycle co-ordination between donor and recipient to prevent DNA damage and maintain ploidy (for a review, see Campbell et al., 1996b). As described above, subsequent studies have shown that the cell cycle of both the donor and recipient cells at the time of NT can have significant effects upon epigenetic modification of the donor chromatin and subsequent development. This review hypothesizes that the cell cycle may have further implications for embryo development via mechanisms that co-ordinate cell growth, cell division and cell differentiation. The method of embryo reconstruction, cell cycle stage at enucleation, presence or absence of the recipient nucleus at the time of nuclear transfer and the activation process may affect epigenetic reprogramming of the donor nucleus. Further perturbations in development may also be associated with the removal of cell cycle regulators during the enucleation process. In summary, a greater understanding of the regulation of cell growth and division during embryo and fetal development with particular reference to epigenetic modification of nuclear and chromatin structure is required. More specifically, identification of the proteins removed during enucleation and their role in normal development may help us to devise a more suitable cytoplast recipient.

This article has concentrated on the potential role of the cell cycle in the development of NT embryos; many factors contribute to successful development and other strategies to improve reprogramming and increase the frequency of development are being pursued. Various studies have implied that the epigenetic status varies among types of donor cell and that specific types of cell may be more amenable to reprogramming. In addition, culture conditions of the donor cell can affect its epigenetic status (for a review, see Jaenisch et al., 2003). Permeabilization of the donor nucleus or modification of chromatin structure by chemical treatments to demethylate or hyperacetylate before transfer have been investigated (for a review, see Vignon et al., 2003). More strikingly, it was demonstrated in sheep that somatic cells denatured by heat treatment were capable of producing live offspring (Loi et al, 2002). In this and other laboratories, cytoplasmic extracts from a range of cell types are being used to alter chromatin structure of somatic cells, not only as a means of improving reprogramming after NT, but also as a method for trans-differentiation of somatic cells for autologous cell therapies (Alberio and Campbell, 2003; Hakelien et al., 2002; Hakelien and Collas, 2003).

\section{References}

Adenot PG, Mercier Y, Renard JP and Thompson EM (1997) Differential $\mathrm{H} 4$ acetylation of paternal and maternal chromatin precedes DNA replication and differential transcriptional activity in pronuclei of 1-cell mouse embryos Development 124 4615-4625

Alberio R and Campbell KHS (2003) Inhibition of transcription in bovine foetal fibroblasts exposed to Xenopus laevis egg extracts Theriogenology 59318 (Abstract)

Alberio R, Motlik I, Stojkovic M, Wolf $\mathrm{E}$ and Zakhartchenko V (2000) Behavior of M-phase synchronized blastomeres after nuclear transfer in cattle Molecular Reproduction and Development 57 $37-47$
Baguisi A and Overstrom EW (2000) Induced enucleation in nuclear transfer procedures to produce cloned animals Theriogenology 53209 (Abstract)

Baguisi A, Behboodi E, Melican DT et al. (1999) Production of goats by somatic cell nuclear transfer Nature Biolechnology $17456-461$

Baran V, Vignon X, Lebourhis D, Renard JP and Flechon JE (2002) Nucleolar changes in bovine nucleotransferred embryos Biology of Reproduction $66534-$ 543

Betthauser I, Forsberg E, Augenstein M et al. (2000) Production of cloned pigs from in vitro systems Nature Biotechnology 18 1055-1059 
Bordignon V and Smith LC (1998) Telophase enucleation: an improved method to prepare recipient cytoplasts for use in bovine nuclear transfer Molecular Reproduction and Development 49 29-36

Bordignon V, Clarke HJ and Smith LC (2001) Factors controlling the loss of immunoreactive somatic histone $\mathrm{H} 1$ from blastomere nuclei in oocyte cytoplasm: a potential marker of nuclear reprogramming Developmental Biology 233 192-203

Bourc'his D, Le Bourhis D, Patin D, Niveleau A, Comizzoli P, Renard JP and Viegas-Pequignot E (2001) Delayed and incomplete reprogramming of chromosome methylation patterns in bovine cloned embryos Current Biology 11 1542-1546

Campbell KHS (2002) A background to nuclear transfer and its applications in agriculture and human therapeutic medicine fournal of Anatomy $\mathbf{2 0 0}$ $267-275$

Campbell KHS and Wilmut I (1996) Unactivated oocytes as cytoplast recipients for nuclear transfer patent WO 97/07668

Campbell KHS, Ritchie WA and Wilmut I (1993) Nuclear-cytoplasmic interactions during the first cell cycle of nuclear transfer reconstructed bovine embryos: implications for deoxyribonucleic acid replication and development Biology of Reproduction 49 933-942

Campbell KHS, Loi P, Cappai P and Wilmut I (1994) Improved development to blastocyst of ovine nuclear transfer embryos reconstructed during the presumptive S-phase of enucleated activated oocytes Biology of Reproduction 50 1385-1393

Campbell KHS, Loi P, Otaegui PJ and Wilmut I (1996a) Cloning mammals by nuclear transfer. Co-ordinating nuclear and cytoplasmic events Reviews in Reproduction 1 40-46

Campbell KH, McWhir J, Ritchie WA and Wilmut 1 (1996b) Sheep cloned by nuclear transfer from a cultured cell line Nature 380 64-66

Campbell KHS, Alberio R, Lee JH and Ritchie WA (2001) Nuclear transfer in practice Cloning and Stem Cells 3 201-208

Cerutti L and Simanis V (2000) Controlling the end of the cell cycle Current Biology 10 65-69

Chesne P, Adenot PG, Viglietta C, Baratte M, Boulanger L and Renard JP (2002) Cloned rabbits produced by nuclear transfer from adult somatic cells Nature Biotechnology 20 366-369

Cibelli JB, Stice SL, Golueke PJ, Kane II, Jerry I, Blackwell C, Ponce de Leon FA and Robl JM (1998) Cloned transgenic calves produced from nonquiescent fetal fibroblasts Science 280 1256-1258

Collas P, Balise IJ and Robl JM (1992) Influence of cell cycle stage of the donor nucleus on development of nuclear transplant rabbit embryos Biology of Reproduction 46 492-500

Czolowska R, Modlinski JA and Tarkowski AK (1984) Behaviour of thymocyte nuclei in non-activated and aclivated mouse oocytes Journal of Cell Science 69 19-34

Czolowska R, Waksmundzka $M$, Kubiak IZ and Tarkowski AK (1986) Chromosome condensation activity in ovulated metaphase If mouse oocytes assayed by fusion with interphase blastomeres lournal of Cell Science 84 129-138

Daniels R, Hall VJ, French AJ, Korfiatis NA and Trounson AO (2001) Comparison of gene transcription in cloned bovine embryos produced by different nuclear transfer techniques Molecular Reproduction and Development 60 281-288

Dean W, Santos F, Stojkovic M, Zakhartchenko V, Walter J, Wolf E and Reik W (2001) Conservation of methylation reprogramming in mammalian development: aberrant reprogramming in cloned embryos Proceedings National Academy of Science USA 98 $13734-13738$

Di Berardino MA and Hoffner NJ (1983) Gene reactivation in erythrocytes: nuclear transplantation in oocytes and eggs of Rana. Science 219 862 -864

Edgar BA and Lehner CF (1996) Developmental control of cell cycle regulators: a fly's perspective Science 274 T646-1652

Eggan K, Akutsu H, Hochedlinger K, Rideout W, Yanagimachi $\mathbf{R}$ and Jaenisch R (2000) XChromosome inactivation in cloned mouse embryos Science 290 1578-1581

Fero ML, Rivkin M, Tasch M et al. (1996) A syndrome of multiorgan hyperplasia with features of gigantism, tumorigenesis and female sterility in p27(Kip1)deficient mice Cell 85 733-744

Franklin DS, Godfrey VL, Lee H, Kovalev Gl, Schoonhoven R, Chen-Kiang S, Su L and Xiong $\mathrm{Y}$ (1998) CDK inhibitors p18(INK4c) and p27(Kip1) mediate two separate pathways to collaboratively suppress pituitary tumorigenesis. Genes and Development 12 2899-2911

Gallego C, Gari E, Colomina N, Herrero E and Aldea M (1997) The CIn3 cyclin is down-regulated by translational repression and degradation during the G1 arrest caused by nitrogen deprivation in budding yeast EMBO Journal 16 7196-7206

Gurdon IB and Colman A (1999) The future of cloning Nature 402 743-746

Hakelien AM and Collas P (2003) Novel approaches to transdifferentiation Cloning and Stem Cells 4379 388

Hakelien AM, Landsverk HB, Robl JM, Skalhegg BS and Collas P (2002) Reprogramming fibroblasts to express T-cell functions using cell extracts Nature Biotechnology $20460-466$

Han YM, Kang YK, Koo DB and Lee KK (2003) Nuclear reprogramming of cloned embryos produced in vitro. Theriogenology $5933-44$

Hoffiner NJ and Di Berardino MA (1980) Developmental potential of somatic nuclei transplanted into meiotic oocytes of Rana pipiens. Science $209517-519$ 
Hyttel P, Laurincik J, Zakhartchenko V, Stojkovic M, Wolf E, Muller M, Ochis RL and Brem G (2001) Nucleolar protein allocation and ultrastructure in bovine embryos produced by nuclear transfer from embryonic cells Cloning 3 69-82

Jaenisch R, Eggan K, Humpherys D, Rideout W and Hochedlinger K (2003) Nuclear cloning, stem cells, and genomic reprogramming Cloning and Stem Cells $4389-396$

Jiang W, limenez G, Wells NJ, Hope TJ, Wahl GM, Hunter $\mathrm{T}$ and Fukunaga R (1998) PRC1: a human mitotic spindle associated CDK substrate protein required for cytokinesis Molecular Cell 2 $877-885$

John PC, Mews M and Moore R (2001) Cyclin/Cdk complexes: their involvement in cell cycle progression and mitotic division Protoplasma 216 119-142

Johnston GC, Pringle IR and Hartwell LH (1977) Coordination of growth with cell division in the yeast Saccharomyces cerevisiae. Experimental Cell Research $10579-98$

Jorgensen P, Nishikawa JL, Breitkreutz BJ and Tyers $\mathbf{M}(2002)$ Systematic identification of pathways that couple cell growth and division in yeast Science 297 395-400

Kang YK, Koo DB, Park JS, Choi YH, Chung AS, Lee KK and Han YM (2001a) Aberrant methylation of donor genome in cloned bovine embryos Nature Genetics $28 \quad 173-177$

Kang YK, Koo DB, Park JS, Choi YH, Kim HN, Chang WK, Lee KK and Han YM (2001b) Typical demethylation events in cloned pig embryos. Clues on speciesspecific differences in epigenetic reprogramming of a cloned donor genome Journal of Biological Chemistry $27639980-39984$

Kang YK, Koo DB, Park JS, Choi YH, Lee KK and Han YM (2001c) Influence of oocyte nuclei on demethylation of donor genome in cloned bovine embryos FEBS Letters 499 55-58

Kang YK, Park IS, Koo DB, Choi YH, Kim SU, Lee KK and Han YM (2002) Limited demethylation leaves mosaic-type methylation states in cloned bovine preimplantation embryos EMBO Journa/ 21 1092-1100

Kanka J (2003) Gene expression and chromatin structure in the pre-implantation embryo Theriogenology $593-19$

Kanka J, Smith SD, Soloy E, Holm P and Callesen H (1999) Nucleolar ultrastructure in bovine nuclear transfer embryos Molecular Reproduction and Development 52 253-263

Kato Y, Tani T, Sotomaru Y, Kurokawa K, Kato J, Doguchi $\mathbf{H}$, Yasue $\mathbf{H}$ and Tsunoda $\mathbf{Y}$ (1998) Eight calves cloned from somatic cells of a single adult Science 282 2095-2098

Kato Y, Tani T and Tsunoda Y (2000) Cloning of calves from various somatic cell types of male and female adult, newborn and fetal cows Journal of Reproduction and Fertility $120231-237$
Kipreos ET, Lander LE, Wing JP, He WW and Hedgecock EM (1996) cul-1 is required for cell cycle exit in C. elegans and identifies a novel gene family Cell $85829-839$

Kirschner M, Newport J and Gerhart J (1985) The timing of early developmental events in Xenopus. TIG $041-47$

Kiyokawa H, Kineman RD, Manova-Todorova KO et al. (1996) Enhanced growth of mice lacking the cyclindependent kinase inhibitor function of p27(Kip1) Cell $85721-732$

Kozma SC and Thomas G (2002) Regulation of cell size in growth, development and human disease: PI3K, PKB and S6K Bioessays 24 65-71

Kubisch HM, Larson MA and Roberts RM (1998) Relationship between age of blastocyst formation and interferon-tau secretion by in vitro-derived bovine embryos Molecular Reproduction and Development $49254-260$

Kwon OY and Kono T (1996) Production of identical sextuplet mice by transferring metaphase nuclei from four-cell embryos Proceedings National Academy of Science USA $9313010-13013$

Laurincik J, Zakhartchenko V, Stojkovic M, Brem G, Wolf E, Muller M, Ochs RL and Maddox-Hyttel P (2002) Nucleolar protein allocation and ultrastructure in bovine embryos produced by nuclear transfer from granulosa cells Molecular Reproduction and Development 61 477-487

Leonard RA, Hoffner NJ and Diberardino MA (1982) Induction of DNA synthesis in amphibian erythroid nuclei in Rana eggs following conditioning in meiotic oocytes Developmental Biology $92343-$ 355

Lew DJ (2000) Cell-cycle checkpoints that ensure coordination between nuclear and cytoplasmic events in Saccharomyces cerevisiae. Current Biology $1047-$ 53

Lin SC, Skapek SX and Lee EY (1996) Genes in the RB pathway and their knockout in mice Seminars in Cancer Biology 7 279-289

Liu L, Dai Y and Moor RM (1997) Nuclear transfer in sheep embryos: the effect of cell-cycle coordination between nucleus and cytoplasm and the use of in vitro matured oocytes Molecular Reproduclion and Development 47 255-264

Loi P, Clinton M, Barboni B, Fulka I, Ir, Cappai P, Feil R, Moor RM and Plak G (2002) Nuclei of nonviable ovine somatic cells develop into lambs after nuclear transplantation Biology of Reproduction 67 126-132

McLay DW, Carroll J and Clarke HJ (2002) The ability to develop an activity that transfers histones onto sperm chromatin is acquired with meiotic competence during oocyte growth Developmental Biology 241 195-206

Matsuo K, Silke J, Georgiev O, Marti P, Giovannini N and Rungger D (1998) An embryonic demethylation 
mechanism involving binding of transcription factors to replicating DNA EMBO Journal 17 1446-1453

Mayer W, Niveleau A, Walter J, Fundele $R$ and Haaf T (2000) Demethylation of the zygotic paternal genome Nature 403 501-502

Meek J (2002) Chinese 'first' in world race on cloning The Guardian March 7. hutp://www.guardian.co.uk international/story/0,3604,663191,00.html.

Menssen R, Neutzner A and Seufert W (2001) Asymmetric spindle pole localization of yeast Cdc15 kinase links mitotic exit and cytokinesis Current Biology 11 345-350

Mollinari C, Kleman JP, Jiang W, Schoehn G, Hunter T and Margolis RL (2002) PRC1 is a microtubule binding and bundling protein essential to maintain the mitotic spindle midzone lournal of Cell Biology 157 1175-1186

Monk M, Boubelik M and Lehnert S (1987) Temporal and regional changes in DNA methylation in the embryonic, extraembryonic and germ cell lineages during mouse embryo development Development $99371-382$

Nagahama H, Hatakeyama S, Nakayama K, Nagata M, Tomita K and Nakayama K (2001) Spatial and temporal expression patterns of the cyclin-dependent kinase (CDK) inhibitors p27Kip1 and p57Kip2 during mouse development Anatomy and Embryology (Berlin) 203 77-87

Nakayama K, Ishida N, Shirane M, Inomata A, Inoue T, Shishido N, Horii I, Loh DY and Nakayama K (1996) Mice lacking p27(Kip1) display increased body size, multiple organ hyperplasia, retinal dysplasia, and pituitary tumors Cell 85 707-720

Nash R, Tokiwa G, Anand S, Erickson K and Futcher AB (1988) The WHI1+ gene of Saccharomyces cerevisiae tethers cell division to cell size and is a cyclin homolog EMBO lournal 7 4335-4346

Neufeld TP and Edgar BA (1998) Connections between growth and the cell cycle Current Opinion in Cell Biology $10784-790$

Ogura A, Inoue K, Ogonuki N, Noguchi A, Takano K, Nagano R, Suzuki O, Lee J, Ishino F and Matsuda J (2000) Production of male cloned mice from fresh, cultured and cryopreserved immalure Sertoli cells Biology of Reproduction 62 1579-1584

Ohtsubo M and Roberts JM (1993) Cyclin-dependent regulation of $\mathrm{G} 1$ in mammalian fibroblasts Science 259 1908-1912

Onishi A, Iwamoto M, Akita T, Mikawa S, Takeda K, Awata T, Hanada $\mathrm{H}$ and Perry AC (2000) Pig cloning by microinjection of fetal fibroblast nuclei Science 289 1188-1190

Ono Y, Shimozawa N, Ito $\mathrm{M}$ and Kono T (2001) Cloned mice from fetal fibroblast cells arrested at metaphase by a serial nuclear transfer Biology of Reproduction 64 44-50

Oswald J, Engemann S, Lane N, Mayer W, Olek A, Fundele R, Dean W, Reik W and Walter J (2000)
Active demethylation of the paternal genome in the mouse zygote Current Biology $10475-478$

Perreault SD (1992) Chromatin remodeling in mammalian zygotes Mutation Research: Reviews in Gcnetic Toxicology 296 43-55

Phelps Cl, Koike C, Vaught TD et al. (2003) Production of alpha 1,3-galactosyltransferase-deficient pigs Science $299411-414$

Polejaeva IA, Chen SH, Vaught TD ef al. (2000) Cloned pigs produced by nuclear transfer from adult somatic cells Nature $40786-90$

Polymenis M and Schmidt EV (1997) Coupling of cell division to cell growth by translational control of the G) cyclin CLN3 in yeast Genes and Developmenl $112522-2531$

Polymenis M and Schmidt EV (1999) Coordination of cell growth with cell division Current Biology 976 80

Quelle DE, Ashmun RA, Shurtleff SA, Kato J, Bar-Sagi D, Roussel MF and Sherr CJ (1993) Overexpression of mouse D-type cyclins accelerates G1 phase in rodent fibroblasts Genes and Development 7 15591571

Reik W, Santos F and Dean W (2003) Mammalian epigenomics: reprogramming the genome for development and therapy Theriogenology 59 21-32

Resnitzky D, Gossen M, Bujard H and Reed SI (1994) Acceleration of the G1/S phase transition by expression of cyclins D1 and $E$ with an inducible system Molecular and Cellular Biology 14 1669-1679

Robl JM (2003) Artificial chromosome vectors and expression of complex proteins in transgenic animals Theriogenology 4 107-114

Santos F, Hendrich B, Reik W and Dean W (2002) Dynamic reprogramming of DNA melhylation in the early mouse embryo Developmental Biology 241 172-182

Schnieke AE, Kind Al, Ritchie WA, Mycock K, Scott AR, Ritchie M, Wilmut I, Colman A and Campbell KHS (1997) Human factor IX transgenic sheep produced by transfer of nuclei from transfected fetal fibroblasts Science $2782130-2133$

Shin T, Kraemer D, Pryor J, Liu L, Rugila J, Howe L, Buck S, Murphy K, Lyons L and Westhusin M (2002) Cell biology: a cat cloned by nuclear transplantation Nature 415859

Stancheva I, El Maarri O, Walter J, Niveleau A and Meehan RR (2002) DNA methylation at promoter regions regulates the timing of gene activation in Xenopus laevis embryos Developmental Biology 243 155-165

Szollosi D, Czoeowska R, Szollosi MS and Tarkowski AK (1988) Remodeling of mouse thymocyte nuclei depends on the lime of their transier into activated, homologous oocytes Journal of Cell Science 91 (Pt 4) 603-613

Tani T, Kato Y and Tsunoda $Y$ (2001) Direct exposure of chromosomes to nonactivated ovum cytoplasm is 
effective for bovine somatic cell nucleus reprogramming Biology of Reproduction 64 324-330

Tapon N, Moberg KH and Hariharan IK (2001) The coupling of cell growth to the cell cycle Current Opinion in Cell Biology 13 731-737

Vettese-Dadey M, Grant PA, Hebbes TR, Robinson C, Allis CD and Workman IL (1996) Acetylation of histone $\mathrm{H} 4$ plays a primary role in enhancing transcription factor binding to nucleosomal DNA in vitro. EMBO Journal $152508-2518$

Vignon X, Chesne P, Le Bourhis D, Flechon JE, Heyman Y and Renard JP (1998) Developmental potential of bovine embryós reconstructed from enucleated matured oocytes fused with cultured somatic cells $C R$ Academie des Science III 321 735-745

Vignon X, Zhou Q and Renard JP (2003) Chromatin as a regulative architecture of the early developmental functions of mammalian embryos after fertilization or nuclear rransfer Cloning and Stem Cells $4363-$ 378

Wakayama T and Yanagimachi R (1999a) Cloning of male mice from adult tail tip cells Nature Genetics $22 \quad 127-128$

Wakayama T, Perry AC, Zuccotti M, Johnson KR and Yanagimachi R (1998) Full term development of mice from enucleated oocytes injected with cumulus cell nuclei Nature 394 369-374

Wakayama T, Rodriguez I, Perry AC, Yanagimachi R and Mombaerts P (1999b) Mice cloned from embryonic stem cells Proceedings National Academy of Science USA $9614984-14989$

Wang XM, Yew N, Peloquin JG, Vande Woude GF and Borisy GG (1994) Mos oncogene product associates with kinetochores in mammalian somatic cells and disrupts mitotic progression Proceedings National Academy of Science L/SA $918329-8333$

Wells DN, Miscia PM and Tervit HR (1999) Production of cloned calves following nuclear transfer with cultured adult mural granulosa cells Biology of Reproduction 60 996-1005

Wells DN, Misica PM, Forsyth JT, Berg MC, Lange JM, Tervit HR and Vivanco WH (1999) The use of adult somatic cells nuclear transfer to preserve the last surviving cow of the Enderby island cattle breed Theriogenology $217-$

Wells DN, Laible G, Tucker FC et al. (2003) Coordination between donor cell type and cell cycle stage improves nuclear cloning efficiency in cattle Theriogenology 59 45-59

Wilmut I, Schnieke AE, McWhir J, Kind AJ and Campbell KH (1997) Viable offspring derived from fetal and adult mammalian cells Nature 385810 813

Wittenberg C and Reed SI (1996) Plugging it in signaling circuits and the yeast cell cycle Current Opinion in Cell Biology $8223-230$
Woods GL, White KL, Vanderwall DK, Li GP, Aston KI, Bunch TD, Meerdo $\mathrm{LN}$ and Pate BJ (2003) A mule cloned from fetal cells by nuclear transfer. ScienceExpress. http://www,sciencexpress. org/29May2003/Pagel/10.1126/science. 1086743.

Wrenzycki C, Wells D, Herrmann D, Miller A, Oliver J, Tervit $\mathbf{R}$ and Niemann $\mathbf{H}$ (2001) Nuclear transfer protocol affects messenger RNA expression patterns in cloned bovine blastocysts Biology of Reproduction 65 309-317

Xue F, Tian XC, Du F, Kubota C, Taneja M, Dinnyes A, Dai Y, Levine $H$, Pereira LV and Yang $X(2002)$ Aberrant patterns of $\mathrm{X}$ chromosome inactivation in bovine clones Nature Genetics 31 216-220

Yan $\mathrm{Y}$, Frisen J, Lee $\mathrm{MH}$, Massague J and Barbacid $M$ (1997) Ablation of the CDK inhibitor p57Kip2 results in increased apoptosis and delayed differentiation during mouse development Genes and Development 11 973-983

Yoshida S, Asakawa K and Toh-EA (2002) Mitotic exit network controls the localization of $\mathrm{Cdc} 14$ to the spindle pole body in Saccharomyces cerevisiae. Current Biology 12 944-950

Zakhartchenko V, Durcova-Hills G and et al. (1999a) Potential of retal germ cells for nuclear transfer in cattle Molecular Reproduction and Development 52 421-426

Zakhartchenko V, Alberio R, Stojkovic M et al. (1999b) Adult cloning in cattle: potential of nuclei from a permanent cell line and from primary cultures Molecular Reproduction and Development $\mathbf{5 4}$ 264-272

Zakhartchenko V, Mueller, Alberio R et al. (2001) Nuclear transfer in cattle with non-transfected and transfected fetal or cloned transgenic fetal and postnatal fibroblasts Molecular Reproduction and Development $60362-369$

Zhang $P$, Liegeois NJ, Wong $C$, Finegold $M$, Hou $H$, Thompson JC, Silverman A, Harper JW, Depinho RA and Elledge S) (1997) Altered cell differentiation and proliferation in mice lacking P57KIP2 indicates a role in Beckwith-Wiedemann syndrome Nature 387 151158

Zhang P, Wong C, Depinho RA, Harper JW and Elledge SJ (1998) Cooperation between the Cdk inhibitors p27(KIP1) and p57(KIP2) in the control of tissue growth and development Genes and Development $123162-3167$

Zhou Q, Joueau A, Brochard V, Adenot P and Renard JP (2001) Developmental potential of mouse embryos reconstructed from metaphase embryonic stem cell nuclei Biology of Reproduction 65 412-419

Zhou RP, Oskarsson M, Paules RS, Schulz N, Cleveland D and Vande Woude GF (1991) Ability of the C-mos product to associate with and phosphorylate tubulin Science $251671-675$ 